\title{
Bioactive Bead Type Cellulosic Adsorbent for Blood Purification
}

Shenqi Wang and Yaoting Yu

Additional information is available at the end of the chapter

http://dx.doi.org/10.5772/56223

\section{Introduction}

Cellulose, a natural polymer, has been widely used in blood purification due to its good biocompatibility, and excellent processing which can be easily formulated into beads, membranes and hollow fibers. Sorbent-perfusion is a novel approach of blood purification which can specifically remove endogenous and exogenous pathogenic toxins from the blood of patients [1]. The technique involves passing whole blood or plasma of the patient through a cartridge filled with an adsorbent which can easily adsorb the toxin molecules, see Figure $1 \mathbf{a}, \mathbf{b}$. According to selectivity, generally adsorbents can be classified as broad spectrum, affinity adsorbents and immuno-adsorbents, of which the latter has the highest selectivity [2-5]. Materials, most commonly used are activated charcoal [6], porous resins and fibers. The pathogenic substances in the blood of patients are adsorbed by the adsorbent via hydrophilic (electro-static forces) or hydrophobic interactions. Macroporous resins usually show high adsorption capacities especially for the removal of high molecular weight or "middle molecules" toxins [7-9].
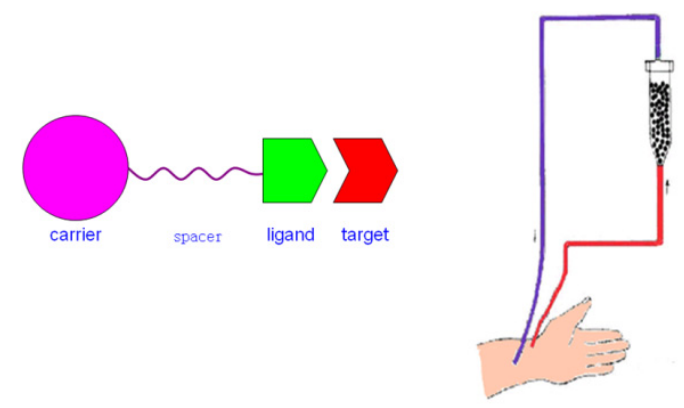

a

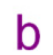

Figure 1. Schematic diagram of sorbent-perfusion 


\section{Preparation and activation of cellulosic beads}

\subsection{Preparation of cellulosic beads $[10,11]$}

One hundred grams of cotton (medical grade) was soaked in a flask containing $19 \% \mathrm{NaOH}$ solution for $3 \mathrm{~h}$ at room temperature. The cotton was squeezed and weighed then placed in a $1500 \mathrm{ml}$ conical flask at $25^{\circ} \mathrm{C}$ for 3 days. Fifty milliliters of carbon disulfide was added to the conical flask which was then sealed and aged for $5 \mathrm{~h}$ to convert the cellulose into a viscose solution, which was then diluted to $1000 \mathrm{ml}$ with $6 \% \mathrm{NaOH}$ solution to make a $10 \%$ viscous solution of cellulose. In a reactor equipped with a stirrer, a mixture of $800 \mathrm{ml}$ chlorobenzene, $200 \mathrm{ml}$ carbon tetrachloride and $2.0 \mathrm{~g}$ of potassium oleate was stirred for 30 $\mathrm{min}$ at $300 \mathrm{rpm}$ under room temperature. Then $300.0 \mathrm{ml}$ of $10 \%$ cellulose viscose solution was added to the reactor slowly and continued stirring for $30 \mathrm{~min}$ until the liquid particles were dispersed uniformly. Thereupon, the temperature was slowly raised to $90^{\circ} \mathrm{C}$ and kept for $2.5 \mathrm{~h}$, after which it was cooled to room temperature to solidify the liquid particles into resin beads. Cellulosic beads were filtered (20-40 mesh) and washed thoroughly with alcohol and distilled water to remove all the impurities.

Compared to the gel type cellulosic beads, macroporous beads can greatly enhance the adsorption capacity for middle and high molecules in the therapeutic embolization of meningiomas [12-15]. It can be synthesized according to reference [16, 17]. In brief, a certain amount of pore-forming agent such as calcium carbonate granules, with an average diameter of about $0.2 \mathrm{~mm}$ was added to a $10 \%$ viscous solution of cellulose, then mixed and dispersed to form cellulosic beads. After washing with dilute $\mathrm{HCl}$ to remove the poreforming agent, various kinds of porous adsorbents could be prepared. Alternatively, macroporous cellulose beads could also be prepared from cellulose solution in ionic liquid by double emulsification $[18,19]$.

Recently, cellulosic microspheres with a particle size below $5 \mu \mathrm{m}$ have been widely adopted in blood purification [20, 21], which can be an excellent matrix for the preparation of adsorbent.

Bead porosity and density are calculated by the following equations: [10, 17]

$$
\begin{gathered}
P=\frac{\rho_{s} \times Q}{\rho_{s} Q+(1-Q) \rho_{\mathrm{H}_{2} \mathrm{O}}} \times 100 \% \\
D_{P}=\frac{w t_{w}}{V_{W}} \\
Q=\frac{w t_{w}-w t_{d}}{w t_{w}} \times 100 \%
\end{gathered}
$$

where $P$ stands for porosity percentage; $r_{s}$ stands for skeleton density; $Q$ stands for water content; $\rho$ H2O stands for density of water; $w t_{w}$ stands for weight of wet beads; $w t_{d}$ stands for weight of dried beads; $V w$ stands for volume of wet beads; $D p$ stands for packing density. 
Adsorption percentage and capacity can be calculated by the following equations,

$$
\begin{gathered}
A P=\frac{[C]_{B}-[C]_{A}}{[C]_{B}} \times 100 \% \\
A C=\left(\left[C_{B}\right]-[C]_{A}\right) \times V_{P}
\end{gathered}
$$

Where $A P$ and $A C$ stand for adsorption percentage and adsorption capacity respectively; $[C]_{B}$ is the concentration before adsorption, $[C]_{A}$ is the concentration after adsorption, $V_{P}$ is the volume of plasma used during adsorption.

\subsection{Activation of cellulose beads}

Cellulose can be easily activated by reaction with epichlorohydrin which is frequently used for the preparation of cellulosic adsorbent [10,22,23].Briefly, 10 grams of cellulosic beads was activated with $10 \mathrm{ml}$ epichlorohydrin in $20 \mathrm{ml} 2 \mathrm{~mol} / 1$ sodium hydroxide solution. The mixture was stirred at $40^{\circ} \mathrm{C}$ for $4 \mathrm{~h}$. Then the epoxy-activated cellulosic beads was washed thoroughly with distilled water and further reacted with amino acids or proteins, see Figure 2. The concentration of sodium hydroxide solution used in the condensation reaction plays an important role on the amount of activated expoxy groups linked onto cellulose. This is attributed to the condensation and ring opening reaction of epichlorohydrin molecule that competes in the reactions, see Figure 3.

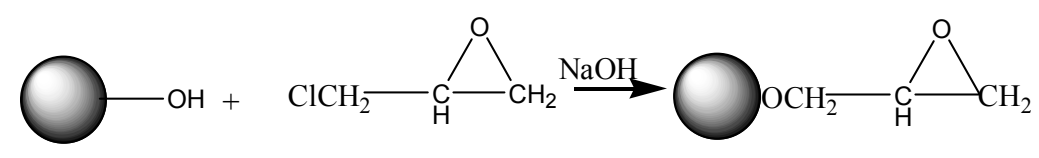

epoxy reaction
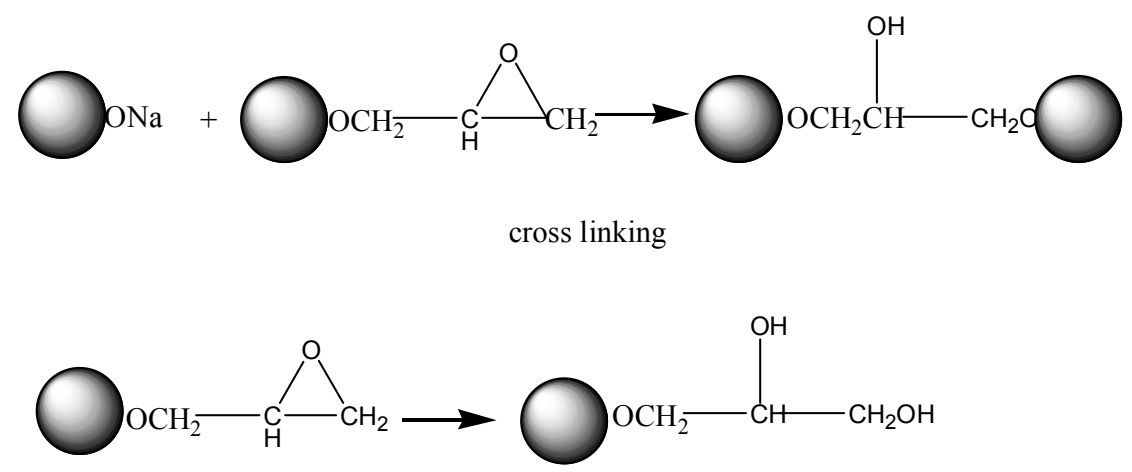

ring-opening reaction

Figure 2. Activation reaction of cellulosic beads 


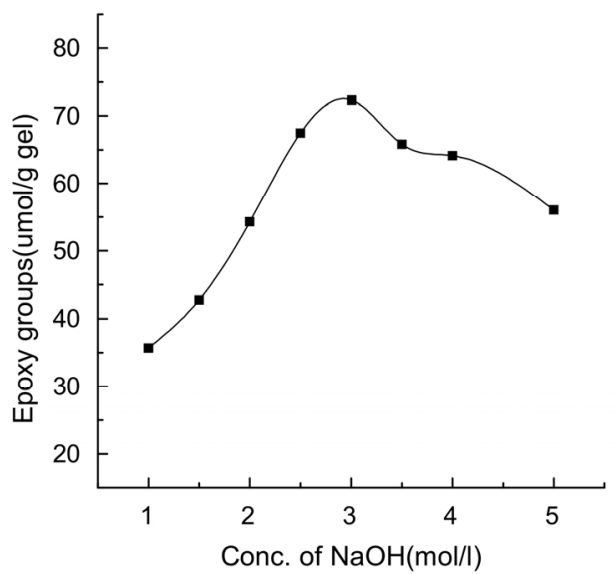

Figure 3. Amount of epoxy groups on cellulose versus concentration of $\mathrm{NaOH}$

\section{Mechanism study of molecular recognition between the ligand and the pathogenic toxic molecule.}

\subsection{Molecular recognition}

To understand the interaction mechanism of pathogenic toxins with different ligands is essential, since it not only provides fundamental insight to biomaterial science, but also can lead to the discovery of more efficient ligands for the removal of pathogenic toxins in human blood. Chemical modification of proteins has been frequently used in the studies of structure-function relationships of proteins, especially in the determination of the active sites in biologically active proteins $[23,24]$. In the present study, we selectively modified the arginine, tryptophan, lysine residues and carboxyl terminus on the protein for the molecular recognition studies.

Lianyong Wang et al [25] investigated the interaction between ss- DNA and IgGRF by selectively modification of the arginine, tryptophan, lysine residues and carboxyl terminus on IgGRF, which was purified from patients' serum. It is well known that the density of negative charge is high on the surface of ss-DNA molecule, due to the large amount of phosphate groups. After the ss-DNA was covalently attached to the cellulose carrier, the immunoadsorbent is negatively charged, so it has a high adsorption capacity for the positively charged $N$-bromosuccinimide (NBS) modified IgGRF. The same situation occurred when $N$-Ethyl- $N$ '-[3-(dimethylamino)propyl]carbodiimide( EDC) modified IgGRF because of its decrease in negatively charged density. The low adsorption capacity for 1, 2cyclohexanedion (CHD) and pyridoxal 5-phosphate (PP) modified IgGRF may be attributed to the reduction of positively charged density after modification. From all the experimental results, it is assumed that there is an ionic bond formed between the modified IgGRF and the ss-DNA immobilized immunoadsorbent. 
Shenqi Wang and Yaoting $\mathrm{Yu}$ et al [24] studied the mechanism of recognition and interactions of low density lipoprotein cholesterol (LDL-C) with different charged ligands on the adsorbents. Tryptophan, lysine residues and carboxyl terminus on LDL were chemically modified by PP, EDC and NBS respectively. Due to the effectiveness of L-lysine in the removal of LDL-C, it was selected to study the interaction of ligand with the modified LDL. Experimental results show that positive charge on the surface of LDL interacted with the negatively charged carboxyl groups of L-lysine by electrostatic force, thus resulting in the adsorption of LDL by the absorbent. We also found that increasing the positive charge on the surface of LDL could enhance the adsorption capacity of the adsorbent. On the contrary, increasing the negative charge could decrease the adsorption ability. Thus, different adsorbents containing sulfonic groups, phosphoric groups, L-lysine and carboxyl groups as the ligand were synthesized for investigating the effect of electric charge on their adsorption capacity. Results show that the adsorption capacity increases with the increase of the electro-negativity of the ligand on the adsorbent. See Table1

\begin{tabular}{ccccc}
\hline \multirow{2}{*}{$\begin{array}{c}\text { Terminus group } \\
\text { of adsorbent }\end{array}$} & $\begin{array}{c}\text { Adsorption } \\
\text { percentage }(\%)\end{array}$ & $\begin{array}{c}\text { Adsorption } \\
\text { capacity } \\
(\mathrm{mg} / \mathrm{ml})\end{array}$ & $\begin{array}{c}\text { Adsorption } \\
\text { percentage }(\%)\end{array}$ & $\begin{array}{c}\text { Adsorption } \\
\text { capacity } \\
(\mathrm{mg} / \mathrm{ml})\end{array}$ \\
\hline$-\mathrm{SO}_{3}{ }^{2-}$ & 52.58 & 1.998 & 60.9 & 1.432 \\
$-\mathrm{PO}_{4}{ }^{3-}$ & 43.86 & 1.667 & 44.25 & 1.039 \\
$\mathrm{PP}-\mathrm{PO}_{4}^{3-}$ & 40.39 & 1.535 & 39.51 & 0.928 \\
$\mathrm{DNA}-\mathrm{PO}_{4}^{3-}$ & 34.94 & 1.328 & 33.14 & 0.778 \\
L-lysine-COO- $^{-1}$ & 31.68 & 1.203 & 27.98 & 0.657 \\
$-\mathrm{COO}-$ & 26.02 & 0.989 & 13.75 & 0.323 \\
\hline
\end{tabular}

Source: Wang S Q et al, Reactive \& Functional Polymers (2008), 68: 261-267

Table 1. Adsorption capacity and percentage of total cholesterol(TC), LDL-C by cellulosic beads having different terminus groups

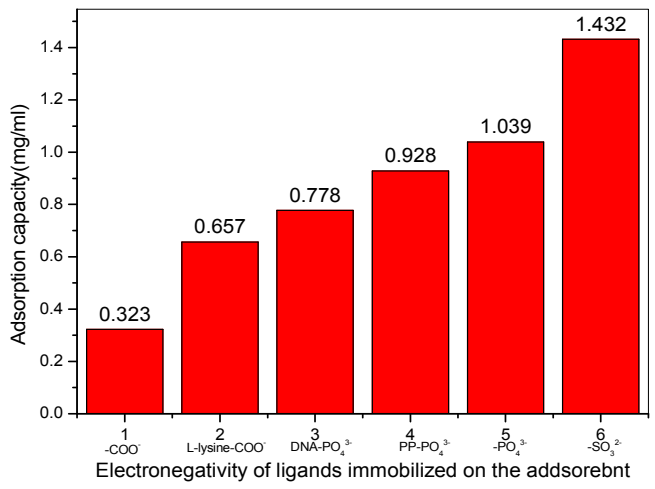

(From Wang S Q et al, Reactive \& Functional Polymers (2008), 68: 261-267, adapted)

Figure 4. The relationship of absorption capacity versus electronegativity of ligands immobilized on the adsorbent 
Experimental results show that the adsorption capacity $(\mathrm{mg} / \mathrm{ml}$ or percentage) for TC and LDL-C decreased with decreasing of electro-negativity of ligands on the adsorbents $\left(-\mathrm{SO}_{3}{ }^{2-}>-\mathrm{PO}_{4}^{3->}-\mathrm{COO} ;-\mathrm{PO}_{4}^{3->}>\mathrm{PP}-\mathrm{PO}_{4}^{3->} \mathrm{DNA}-\mathrm{PO}_{4}^{3-}\right)$, which demonstrate that the electro-negativity of ligand on adsorbent plays an important role in adsorbing TC and LDLC. This relationship of the adsorption capacity to its electro-negativity is shown in Figure. 4

\subsection{Spacer effect}

Spacers have a significant effect on the adsorption property of the resin adsorbents. It can reduce the steric hindrance between the ligand and the large toxic molecules, resulting in an increase of adsorption capacity of the adsorbent. Different spacers have an obvious effect on the adsorption properties of adsorbents. The density of ligands on the carrier and the effect of steric hindrance are both important factors in specific adsorption. When the target substance is a small molecule, there may be no steric hindrance, see Figure 5 a, so the enhancement of the density of ligands can improve the adsorption capacity. But when the target substance is a large molecule, due to the presence of steric hindrance [26-33], a high density of ligands linked may display a low adsorption capacity of target protein, see Figure $5 \mathbf{b}$. In theory, a flexible spacers can reduce the steric hindrance, see Figure $\mathbf{5 c}$. In order to study flexible spacers play the role in reducing steric hindrance between the target protein and immobilized ligands, Xinji Guo et al [34]designed and prepared cellulosic adsorbents with L-lysine acid as ligands and PEG having different molecule weights as spacers.

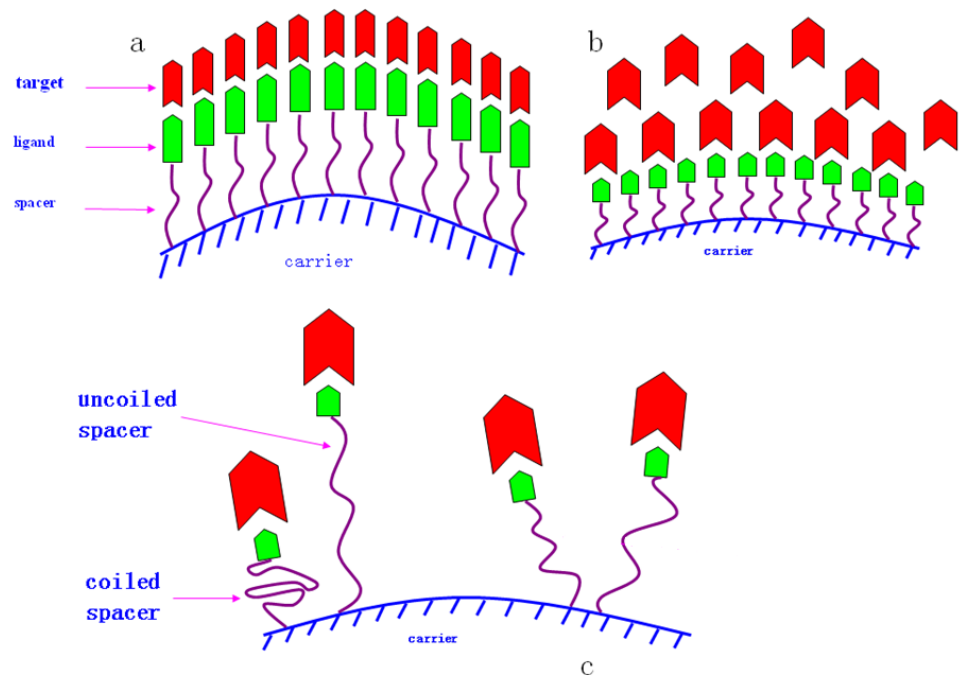

Figure 5. Schematic diagram of interaction between the ligand and target toxins

Note: a, Interaction between small target molecules and the immobilized ligands; $b$, Large target molecules having a steric hindrance to the immobilized ligands; c, Flexible spacer can reduce the steric hindrance, 
In this study, carboxyl modified PEG spacer was synthesized and linked covalently to cellulose beads. L-lysine ligand was coupled to the spacer and its selective affinity for lowdensity lipoprotein-cholesterol (LDL-C) was determined. It was found that the adsorption capacity and the efficiency of the ligand for adsorption of LDL-C were increased when PEG spacer was used. Experimental results showed that by increasing the molecular weight of PEG spacers from 1000Da to 6000Da, the average adsorption capacity of LDL-C was enhanced from $0.242 \mathrm{mg} / \mathrm{ml}$ to $0.903 \mathrm{mg} / \mathrm{ml}$. According to the analytical data of cellulose adsorbents, the amount of L-lysine ligand could be calculated. Although the amount of Llysine linked to the adsorbent with PEG spacers (10.5, 9.8, 9.0, 8.6 $\mathrm{mg}$ per $\mathrm{ml}$ cellulose adsorbent respectively) was lower than those without PEG spacers (121.6mg per ml cellulose adsorbent), see Table 2, the average adsorption capacity for LDL-C per $\mathrm{ml}$ cellulose adsorbent increased from $0.130 \mathrm{mg} / \mathrm{ml}$ to $0.903 \mathrm{mg} / \mathrm{ml}$. After the introduction of PEG spacers, (see Table 3) and consequently the adsorption capacity for LDL-C per unit ligand increased significantly from $0.001 \mathrm{mg} / \mathrm{mg}$ L-lysine to $0.105 \mathrm{mg} / \mathrm{mg}$ L-lysine, see Table 4, the adsorption capacity of LDL-C per unit L-lysine ligand (0.027mg LDL-C/mg L-lysine) was much higher than that without PEG spacer $(0.001 \mathrm{mg}$ LDL-C/mg L-lysine). This result indicated that in the presence of PEG spacer, the adsorption efficiency of L-lysine ligands was enhanced significantly, see Table $\mathbf{5}$. It is postulated that appropriate increasing the amount of the L-lysine ligands and the use of PEG spacers can enhance the adsorption capacity for LDL-C.

\begin{tabular}{ccccc}
\hline \multirow{2}{*}{\begin{tabular}{c} 
Molecular weight $\begin{array}{c}\text { TC } \\
\text { of PEG spacers } \\
(\mathrm{Da})\end{array}$ \\
\cline { 2 - 5 }
\end{tabular}} & $\begin{array}{c}\text { Removal } \\
\text { capacity }(\%)\end{array}$ & $\begin{array}{c}\text { Removal } \\
\text { amount } \\
(\mathrm{mg} / \mathrm{ml})\end{array}$ & $\begin{array}{c}\text { Removal } \\
\text { capacity }(\%)\end{array}$ & $\begin{array}{c}\text { Removal } \\
\text { amount } \\
(\mathrm{mg} / \mathrm{ml})\end{array}$ \\
\hline 1000 & $11.45 \pm 0.35$ & $0.351 \pm 0.011$ & $12.01 \pm 0.79$ & $0.242 \pm 0.017$ \\
2000 & $14.90 \pm 0.69$ & $0.458 \pm 0.020$ & $13.04 \pm 0.71$ & $0.263 \pm 0.013$ \\
4000 & $28.94 \pm 0.33$ & $0.889 \pm 0.011$ & $35.13 \pm 0.69$ & $0.708 \pm 0.017$ \\
6000 & $33.48 \pm 0.33$ & $1.028 \pm 0.011$ & $44.76 \pm 0.36$ & $0.903 \pm 0.003$ \\
\hline
\end{tabular}

Source: Wang S Q et al, Reactive \& Functional Polymers (2008), 68: 261-267

Table 2. Adsorption capacity and adsorption percentage of TC, and LDL-C by cellulosic beads with different molecular weight of PEG as a spacer

\begin{tabular}{ccccc}
\hline $\begin{array}{c}\text { Mol. weight of } \\
\text { PEG spacers } \\
(\mathrm{Da})\end{array}$ & $\begin{array}{c}\text { L-Lysine } \\
\text { amount } \\
(\mathrm{mg} / \mathrm{ml})\end{array}$ & $\begin{array}{c}\text { Average removal } \\
\text { amount of LDL- } \\
\mathrm{C}(\mathrm{mg} / \mathrm{ml})\end{array}$ & $\begin{array}{c}\text { Stoichiometric } \\
\text { capacity (mg LDL- } \\
\text { C/mg L-lysine) }\end{array}$ & $\begin{array}{c}\text { Efficiency of } \\
\text { active site } \\
(\%)^{*}\end{array}$ \\
\hline 1000 & 10.5 & 0.242 & 0.023 & 22 \\
2000 & 9.8 & 0.263 & 0.027 & 26 \\
4000 & 9.0 & 0.708 & 0.079 & 75 \\
6000 & 8.6 & 0.903 & 0.105 & 100 \\
\hline
\end{tabular}

Source: Wang S Q et al, Reactive \& Functional Polymers (2008), 68: 261-267

Table 3. Adsorption capacity of LDL-C per mg L-lysine 


\begin{tabular}{ccccc}
\hline $\begin{array}{c}\text { Mol .weight of } \\
\text { PEG spacers } \\
(\mathrm{Da})\end{array}$ & $\begin{array}{c}\text { L-lysine } \\
\text { amount } \\
(\mathrm{mg} / \mathrm{ml})\end{array}$ & $\begin{array}{c}\text { Average } \\
\text { removal } \\
\text { capacity of LDL } \\
(\mathrm{mg} / \mathrm{ml})\end{array}$ & $\begin{array}{c}\text { Stoichiometric } \\
\text { capacity (mg } \\
\text { LDL/mg L-lysine) }\end{array}$ & $\begin{array}{c}\text { Efficiency of } \\
\text { active site }(\%)^{*}\end{array}$ \\
\hline- & 121.6 & $0.130 \pm 0.013$ & 0.001 & $1.018 \pm 0.098$ \\
1000 & 10.5 & $0.242 \pm 0.017$ & 0.023 & $21.947 \pm 1.469$ \\
2000 & 9.8 & $0.263 \pm 0.013$ & 0.027 & $25.556 \pm 1.178$ \\
4000 & 9.0 & $0.708 \pm 0.017$ & 0.078 & $74.917 \pm 1.549$ \\
6000 & 8.6 & $0.903 \pm 0.003$ & 0.105 & 100.000 \\
\hline
\end{tabular}

Source: Wang S Q et al, Reactive \& Functional Polymers (2008), 68: 261-267

Table 4. Adsorption capacity of LDL -C by L-lysine ligand

\begin{tabular}{ccccc}
\hline & \multicolumn{2}{c}{ CPS-lysine } & \multicolumn{2}{c}{ CPS-PEG1000-lysine } \\
\cline { 2 - 5 } & $\begin{array}{c}\text { Adsorption } \\
\text { capacity }(\mathrm{mg} / \mathrm{g})\end{array}$ & $\begin{array}{c}\text { Adsorption } \\
\text { percentage }(\%)\end{array}$ & $\begin{array}{c}\text { Adsorption } \\
\text { capacity }(\mathrm{mg} / \mathrm{g})\end{array}$ & $\begin{array}{c}\text { Adsorption } \\
\text { percentage }(\%)\end{array}$ \\
\hline TC & 0.664 & 8.769 & 0.402 & 5.31 \\
LDL-C & 1.493 & 33.559 & 4.158 & 93.29 \\
TG & 0.419 & 6.213 & 0.132 & 1.97 \\
HDL-C & 0.204 & 15.170 & 0.341 & 24.48 \\
\hline
\end{tabular}

Source: Wang S Q et al, Reactive \& Functional Polymers (2008), 68: 261-267

Table 5. Adsorption capacity of TC and LDL by CPS beads with and without PEG as spacer

\section{Typical bioactive bead type cellulosic adsorbent for blood purification}

\subsection{Cellulosic adsorbents for removing low density lipoprotein -cholesterol (LDL-C)}

Familial hypercholesterolemia is characterized by a high concentration of plasma cholesterol in the form of low-density lipoprotein-cholesterol (LDL-C). In order to decrease the LDL-C level in patients, drugs and surgical intervention were reported [35]. Sorbent-perfusion treatment is currently employed when the reduction of LDL-C level appears impossible to be achieved by drug administration [36-38]. Since the late 1970s, scientists have been engaged in developing different kinds of adsorbents to remove pathogenic substances [39-41].

Yaoting $\mathrm{Yu}$ and Shenqi Wang et al [42,43] have developed cellulosic adsorbent with amphiphilic ligands for the adsorption of (LDL-C) which was prepared by the following procedure: Cellulose beads were reacted with cholesterol N-(6-isocyanatohexyl) carbamate in the presence of pyridine in DMSO at $80^{\circ} \mathrm{C}$ in order to introduce the hydrophilic moiety. It was then reacted with chlorosulfonic acid in dimethyl formamide to introduce the sulfonic group see Figure 6

The effects of sulfonation and grafting time of cholesterol on the swelling property of adsorbent were studied. Results showed that sulfonation and grafting time of cholesterol 


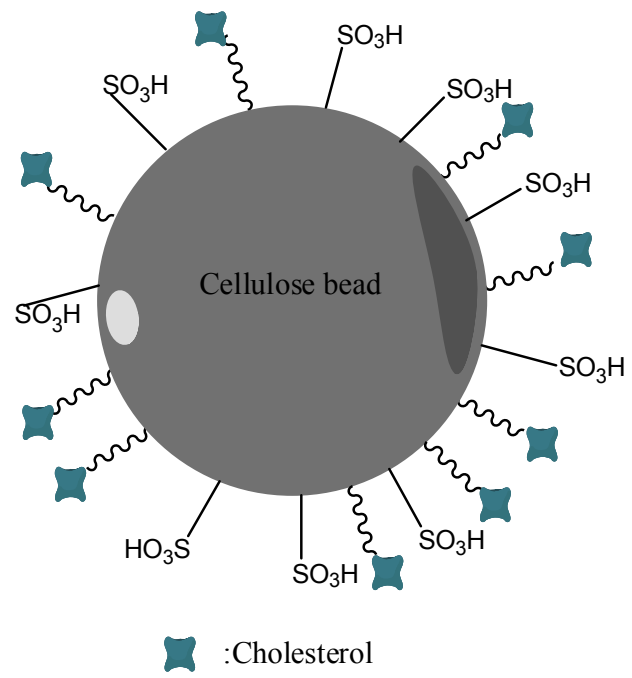

(From Wang S Q et al, Artif Cells Blood Sub (2002), 30: 285-292, adapted)

Figure 6. Schematic structure of amphiphilic cellulose adsorbent

was 3 and $5 \mathrm{~h}$, respectively. The amphiphilic adsorbent had a high adsorption capacity for LDL-C without significantly adsorbing high-density lipoprotein. Rabbit model was constructed according to the following method [44]. In brief, Japanese white male rabbits were purchased from local experimental animal institute and housed in a standard facility. After feeding with standard chow and water ad libitum for one week, the healthy rabbits were divided into control group (group 1, $n=6$ ) and hyperlipidemia group. Rabbits in the control group consumed standard chow from $120-150 \mathrm{~g} / \mathrm{d}$ and water ad libitum. In the hyperlipidemia model group, the rabbits were fed with standard chow supplemented with $0.5-1 \%$ cholesterol, $15 \%$ egg yolk and 5\% animal oil. After 8 weeks, the rabbits in the hyperlipidemia group were further divided into two groups, that was group No.2 $(\mathrm{n}=6)$, (without any treatment) and group No.3 $(\mathrm{n}=6)$, (treated by sorbent-perfusion.). Experimental results showed that the LDL-C levels decreased significantly after $2 \mathrm{~h}$ perfusion indicating the adsorbent could effectively remove LDL-C, see Table 6. Furthermore, sorbent-perfusion also reduced all the subfractions of LDL-C, therefore decreased the risk for the development of atherosclerosis and myocardial infarction, see Table 7.

\begin{tabular}{llll}
\hline Parameter & Before $(\mathrm{mmol} / \mathrm{l})$ & After $(\mathrm{mmol} / \mathrm{l})$ & Reduction $(\%)$ \\
\hline TC & $8.54 \pm 1.01$ & $3.33 \pm 0.63^{*}$, & $61.20 \pm 2.81$ \\
TG & $1.845 \pm 0.191$ & $1.05 \pm 0.153^{*}$, & $43.09 \pm 2.43$ \\
LDL-C & $3.619 \pm 0.354$ & $0.724 \pm 0.07^{*}$, & $78.56 \pm 0.147$ \\
HDL-C & $0.216 \pm 0.06$ & $0.205 \pm 0.057$ & $5.09 \pm 0.042$ \\
\hline
\end{tabular}

Note: $\mathrm{n}=6$,

Source: Wang S Q et al, Biomaterials (2003), 24: 2189-2194

Table 6. Removal of lipoproteins by amphiphilic adsorbent 


\begin{tabular}{llllll}
\hline & \multicolumn{2}{l}{ Before perfusion } & \multicolumn{2}{l}{ After perfusion } & \multirow{2}{*}{ Change=(A-B) } \\
\cline { 2 - 5 } & $\mathrm{mmol} / \mathrm{l}$ & $\%$ & $\mathrm{mmol} / \mathrm{l}$ & $\%$ & \\
\hline LDL-1 & $0.51 \pm 0.061$ & $13.95 \pm 2.1^{*}$ & $0.12 \pm 0.046$ & $15.1 \pm 2.3$ & $8.24 \pm 2.6$ \\
LDL-2 & $1.65 \pm 0.019$ & $45.4 \pm 5.3^{*}$ & $0.38 \pm 0.043$ & $53.4 \pm 5.8^{*}$ & $17.36 \pm 3.4$ \\
LDL-3 & $1.45 \pm 0.052$ & $40.1 \pm 4.7^{*}$ & $0.23 \pm 0.024$ & $31.6 \pm 3.6^{*}$ & $-21.20 \pm 3.9$ \\
\hline
\end{tabular}

Note: $\mathrm{n}=6$

Source: Wang S Q et al, Biomaterials (2003), 24: 2189-2194

Table 7. Removal of LDL-C subfraction by amphiphilic adsorbent

The authors also developed the adsorbent with lysine and phosphate groups as ligand for the treatment of hyperlipidemia [34, 45]. Comparing to the amphiphilic adsorbent, the adsorbent with lysine as ligand has a lower adsorption capacity for LDL-C, total cholesterol and higher HDL-C. On the other hand, the phosphalated cellulosic adsorbent has a higher adsorption capacity for LDL-C and lower for HDL-C, see Table 8.

\begin{tabular}{cccccc}
\hline Sample & 1 & 2 & 3 & 4 \\
\hline Amount of coupled phosphate $(\mu \mathrm{mol} / \mathrm{ml})$ & 0 & 68.4 & 94.3 & 128.6 \\
\hline \multirow{2}{*}{$\begin{array}{c}\text { Adsorption } \\
\text { capacity } \\
(\mathrm{mg} / \mathrm{ml})\end{array}$} & $\mathrm{TC}$ & 0.893 & 0.735 & 0.939 & 1.586 \\
\cline { 2 - 6 } & $\mathrm{LDL}$ & 1.235 & 1.515 & 1.707 & 2.721 \\
\hline
\end{tabular}

Source: Wang T et al, Chinese Journal of Biomedical Engineering ( 2008), 27: 132-136

Table 8. Effect of amount of coupled phosphate on adsorption capacity

Haofeng Yu et al [46] synthesized PAA-grafted cellulosic adsorbent for the removal of LDL$\mathrm{C}$ from human plasma. In-vitro studies showed that this adsorbent could remove total cholesterol (TC), LDL-C, and triglyceride (TG) at levels of 5.55, 4.46, and $2.48 \mathrm{mg} / \mathrm{m} 1$ respectively. Unfortunately, it removed $30 \%$ HDL-C in the plasma.

\subsection{Cellulosic adsorbents for removal of rheumatoid factors}

Rheumatoid Arthritis (RA) is a rather wide-spread immune disease. Spector reported that there is about $1 \%$ of the world's population is infected by this disease. Lianyong Wang and Yaoting $\mathrm{Yu}$ et al [25] covalently linked ss-DNA to cellulosic beads for the removal of rheumatoid factors. In vitro and in vivo studies showed that the adsorbent had a high adsorption capacity for IgMRF, IgGRF and IgARF, see Figure 7. Furthermore, the adsorbent attained good blood compatible properties.

Sorbent-perfusion using the above mentioned adsorbent was conducted on 35 RA patients clinically. Clinical protocol was designed as follows: 46 patients were hospitalized from Dec. 1998 until Nov.2000 and diagnosed as RA sickness. The extent of joint pain, swelling, morning stiffness, nodules under the skin, titer of rheumatoid arthritis factor (RF), value of immune-globulin and X-ray diagnosis of sick ankle etc. were all performed. The patients were divided into several groups from the above 46 patients. 35 of them matched the American Rheumatoid Arthritis Standard of 1987[47]. 


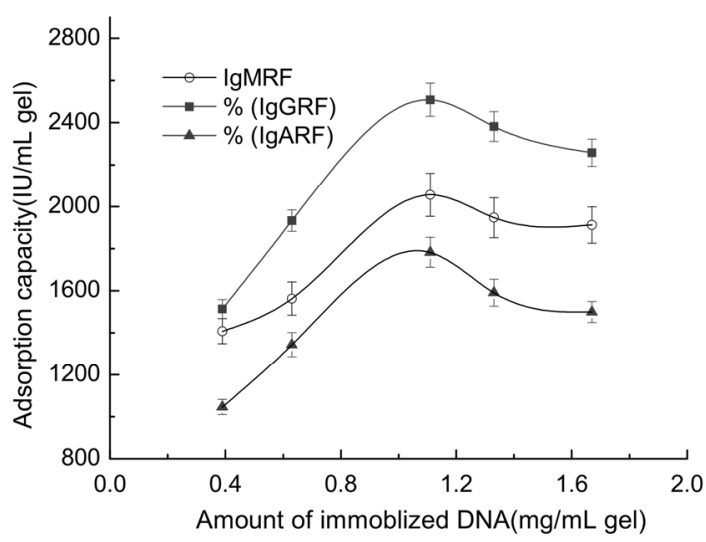

Note:IU is abbreviation of international unit

(Source: Wang L Y et al, Chemical Research in Chinese Universities(2004),20: 795-800)

Figure 7. Adsorption capacity versus amount of DNA immobilized

RA patients were graded into 4 grades according to the functional ability of the sick joint. 11cases having grade II joint sickness, 20 cases having grade III and 1 case having gradeIV. Conventional method of treatment was performed on 30 cases. The control group compared to treated group with a significance of $P>0.05$.

After perfusion the levels of rheumatoid factor was reduced and platelet count showed no significant changes in $35 \mathrm{RA}$ patients $(\mathrm{P}<0.05)$ during treatment. After one week joint pain, swelling, tenderness, morning stiffness disappeared in 90 percent patients; 80 percent abnormal indexes recovered to normal value. After two to three weeks, joint function of 82 percent patients were improved and reached grade II or I. Two to three months later, X-ray examinations showed 80 percent bone matrix destruction was restored. Results of follow-up $(0.67-2.5$ years $)$ proved that effective rate $(97.14 \%, 81.25 \%)$ and total remission rate $(82.86 \%$, $59.38 \%$ ) all had a significant improvement and recovery when compared to routine therapy.

In conclusion, clinical results show that sorbent-perfusion by cellulosic adsorbents is an effective approach for the therapy of rheumatoid arthritis. The treatment is safe, without hemolysis or pyrogenic side reactions, the adsorbent is easy to sterilize and cost effective.

\subsection{Cellulosic adsorbents for removal of endotoxin}

Bacterial endotoxins (ET), frequently named as lipopolysaccharides (LPS), are components of the outer cell wall of gram-negative bacteria and supposed to be a key factor in the pathogenesis of endotoxemia and septic shock $[48,49]$. Sorbent-perfusion is one of the best methods to remove endotoxin. Hui Fang and Yaoting Yu et al [10] synthesized a new type adsorbent for the removal of bacterial endotoxins by immobilizing lysine covalently onto cellulosic beads. Results showed that the adsorbent has good biocompatibility, see Table 9. In order to evaluate the adsorbent's properties, rabbit models were constructed by the following method [10]: Thirteen New Zealand white rabbits (weight 2.0-2.5 Kg) were 
injected intravenously with $0.20 \mathrm{mg}$ LPS (E.coli O55: B5, sigma) to induce endotoxemia after being anaesthetized. The rabbits were classified into two groups, one was the treated group $(n=8)$ perfused through adsorbents while the other was the control group $(n=5)$ without undergoing perfusion. Sorbent-perfusion was conducted 1.5 hours after LPS administration and conventional equipments for perfusion were used. Blood was drawn from the artery and returned to the vein by peristaltic pump (Pharmacia-LKB). The perfusion was carried out at a rate of $5 \mathrm{ml} / \mathrm{min}$ for 2 hours and the adsorbent showed a strong ET-binding capacity. After perfusion, the blood ET level was decreased from $5.56 \pm 0.54 \mathrm{EU} / \mathrm{ml}$ to $0.41 \pm 0.26 \mathrm{EU} / \mathrm{ml}$, see Figure 8. Liver function and renal function tests as well as SOD, malondialdehyde (MDA) assays were conducted. Results all showed that the septic symptoms were ameliorated with the removal of large amounts of ET in the blood which obviously prevented further damage to the organs, see Table 10, Figure 9 and 10.

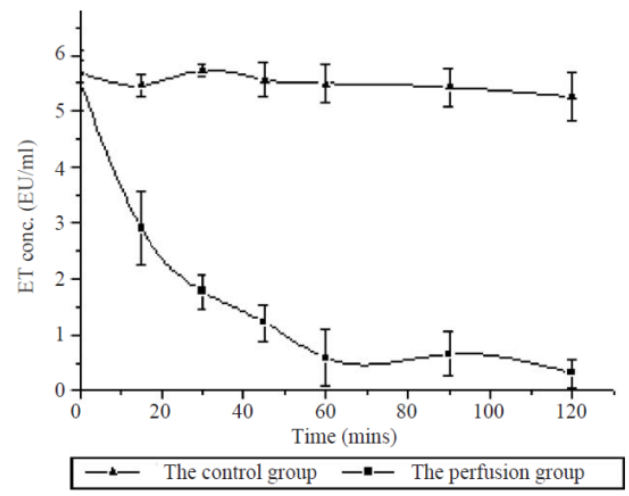

Note: EU is the abbreviation of Endotoxin unit, which is used to indicate the content of endotoxin (From Fang $\mathrm{H}$ and Yu Y T,et al, Biomaterials(2004), 25: 5433-5440)

Figure 8. Removal of ET from rabbit's blood by perfusion using Lys immobilized cellulosic beads

\begin{tabular}{ll}
\hline Parameters tested & Results \\
\hline Hemolysis & $1.1 \%($ standard $<5 \%),(\mathrm{n}=3)$ \\
Platelet adhesion & $18.76 \%(\mathrm{n}=3)(10 \%$ is excellent; $10-30 \%$ is good $)$ \\
Whole body toxicology & Wt. of rat before test Wt. of rat after test \\
& $21.5 \pm 0.61(\mathrm{~g}) 24.4 \pm 2.04(\mathrm{~g})(\mathrm{n}=5)$ \\
Allergic reaction & Grade 1, not higher than negative control $(\mathrm{n}=10)$, \\
Cytotoxicology & none allergic \\
Skin stimulation & $\mathrm{R}^{*}$ index of sample $=0 / 0(\mathrm{n}=6)$, none toxic \\
\hline
\end{tabular}

$R^{*}$ index of sample $=R$ index of extract $-R$ index of sample tested $=0.5 / 0-0.5 / 0=0 / 0, P I I^{* *}$ is the skin stimulation index

Note: The biocompatibility and toxicology tests of the adsorbent were conducted by the Testing and Evaluation Research Centre of Biomedical Materials in Tianjin, China according to the Criteria of GB/T16886.5-1997 in correlation to ISO 10993.4:2002, Source: Fang H and Yu Y T et al, Biomaterials (2004), 25: 5433-5440

Table 9. Biocompatibility and toxicology properties of the adsorbent 


\begin{tabular}{|c|c|c|c|c|}
\hline Parameter & Groups & $0 \mathrm{~min}$ & $60 \mathrm{~min}$ & $120 \mathrm{~min}$ \\
\hline \multirow{2}{*}{$\begin{array}{c}S A \\
(g / L)\end{array}$} & Perfusion & $26.7 \pm 2.4$ & $24.5 \pm 1.8$ & $23.2 \pm 2.3$ \\
\hline & Control & $26.1 \pm 3.7$ & $22.0 \pm 2.2$ & $24.1 \pm 4.6$ \\
\hline \multirow{2}{*}{$\begin{array}{c}\text { TBL } \\
(m g / m l)\end{array}$} & Perfusion & $0.04 \pm 0.01$ & $0.05 \pm 0.02$ & $0.05 \pm 0.01$ \\
\hline & Control & $0.05 \pm 0.01$ & $0.08 \pm 0.03$ & $0.09 \pm 0.02$ \\
\hline \multirow{2}{*}{$\begin{array}{l}\text { AST } \\
(U / L) \\
\end{array}$} & Perfusion & $15.3 \pm 4.0$ & $12.1 \pm 3.2$ & $14.0 \pm 4.2$ \\
\hline & Control & $17.9 \pm 5.7$ & $27.6 \pm 6.9$ & $35.7 \pm 8.0$ \\
\hline \multirow{2}{*}{$\begin{array}{l}A L T \\
(U / L)\end{array}$} & Perfusion & $34.4 \pm 9.5$ & $25.9 \pm 9.1$ & $24.8 \pm 8.5$ \\
\hline & Control & $35.3 \pm 9.9$ & $34.5 \pm 6.2$ & $41.4 \pm 1.8$ \\
\hline \multirow{2}{*}{$\begin{array}{l}A K P \\
(U / L) \\
\end{array}$} & Perfusion & $113.1 \pm 8.5$ & $116.9 \pm 19.2$ & $118.1 \pm 25.7$ \\
\hline & Control & $109.4 \pm 10.3$ & $153.0 \pm 17.3$ & $195.5 \pm 31.2$ \\
\hline \multirow{2}{*}{$\begin{array}{c}\text { BUN } \\
(\mathrm{mmol} / \mathrm{L})\end{array}$} & Perfusion & $5.2 \pm 0.6$ & $4.9 \pm 1.3$ & $4.6 \pm 0.6$ \\
\hline & Control & $5.6 \pm 1.1$ & $7.3 \pm 0.8$ & $7.8 \pm 0.7$ \\
\hline \multirow{2}{*}{$\begin{array}{c}C R K \\
(\text { umol/L) }\end{array}$} & Perfusion & $61.8 \pm 4.8$ & $59.3 \pm 7.5$ & $70.9 \pm 2.0$ \\
\hline & Control & $62.7 \pm 4.2$ & $80.4 \pm 3.7$ & $94.3 \pm 4.7$ \\
\hline
\end{tabular}

Note: $\mathrm{n}=3$

Source: Fang H and Yu Y T ,et al, Biomaterials (2004), 25: 5433-5440

Table 10. Liver and renal function tests

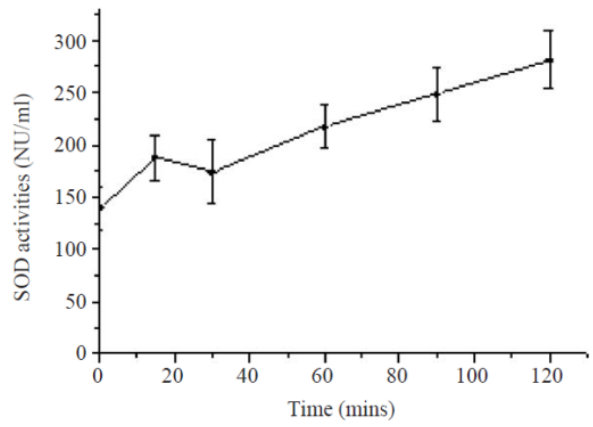

Note: the NU is a unit that is used to indicate the activity of SOD, (From Fang H and Yu Y T et al, Biomaterials (2004), 25: 5433-5440)

Figure 9. Improved activities of serum superoxide dismutase (SOD) versus ET removal by perfusion 


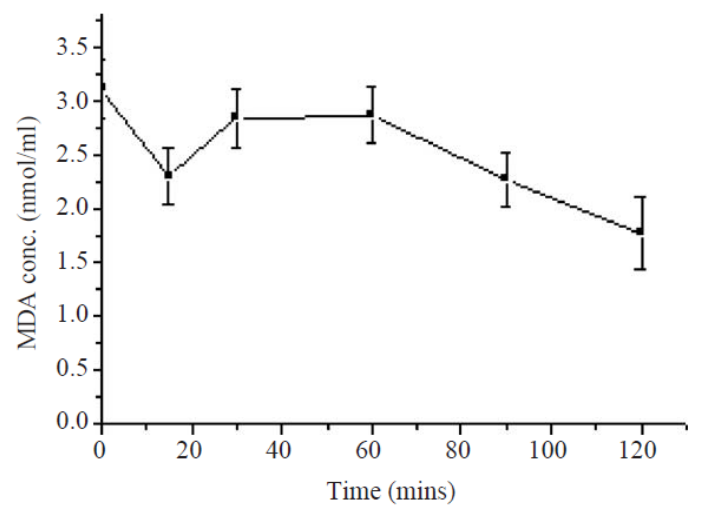

(From Fang H and Yu Y T et al, Biomaterials (2004), 25: 5433-5440)

Figure 10. Decrease in malondialdehyde (MDA) concentrations versus ET removal by perfusion

\subsection{Cellulosic adsorbents for removal of anti-DNA antibody in treatment of systematic lupus erythematosus}

The abnormally high levels of anti-DNA antibodies and immune complex in the sera of systemic lupus erythematosus (SLE) patients can be removed by sorbent- perfusion. Yaoting $\mathrm{Yu}$ and Deling Kong [50] synthesized cellulose adsorbents with DNA as ligand for the removal of anti-DNA antibodies. The activation of cellulosic beads were conducted according to reference [50]: In brief, $2 \mathrm{ml}$ of activated cellulose beads was added to $4.0 \mathrm{ml}$ buffer solution containing $4.0 \mathrm{mg}$ DNA in a flask and stirred at $25^{\circ} \mathrm{C}$ for $20 \mathrm{~h}$ on a shaker. Then the immobilized DNA beads were washed consecutively with buffer solution and water, until no leakage of DNA in the rinse water was detected at $260 \mathrm{~nm}$ by UV spectrometer. The immunoadsorbent thus obtained was stored at $4^{\circ} \mathrm{C}$. In vitro adsorption tests showed that the DNA immuno-adsorbent could remove $40 \%-70 \%$ of anti-DNA antibody from plasma [29]. The maximum decrease of anti-DNA level was $80 \%$ after $60 \mathrm{~min}$ in a dynamic experiment. This high adsorption capacity shows a high potential for clinical application.

\subsection{Cellulosic adsorbent for the treatment of myasthenia gravis}

Myasthenia gravis (MG) is an autoimmune disorder characterized by a disturbance in neuromuscular transmission that results in muscle weakness. Yaoting $\mathrm{Yu}$ and $\mathrm{Li}$ Yang et al $[51,52]$ synthesized immobilized tryptophan cellulosic adsorbent and evaluated its adsorption capacity for binding acetylcholine receptor in the plasma of MG patients. Experimental autoimmune myasthenia gravis (EAMG) rabbits were induced by Ta183-200 peptide according to the following method: Briefly, Female rabbits weighing approximately $2 \mathrm{~kg}$ were injected intradermally at multiple sites with $500 \mu \mathrm{g}$ of Ta183-200, which was emulsified with an equal volume of Freund's complete adjuvant. A booster injection of 500 $\mu \mathrm{g}$ Ta183-200 with Freund's incomplete adjuvant was administered after 4 weeks. 
The rabbits underwent extracorporeal whole blood perfusion for $2 \mathrm{~h}$. Results showed no significant damages on blood cells and changes in the concentration of electrolytes. Whole blood sorbent-adsorption improved clinical manifestation and neuromuscular function of the EAMG rabbits, see Table 11

\begin{tabular}{ccc}
\hline No. of rabbits & Pre WBIA & $5^{\text {th }}$ day after WBIA \\
\hline 1 & + & $0-+$ \\
2 & + & 0 \\
3 & + & 0 \\
4 & + & 0 \\
5 & + & 0 \\
6 & + & 0 \\
7 & ++ & + \\
8 & + & 0 \\
\hline
\end{tabular}

Note : 0 stands for the rabbits recovered normally after therapy

Source: Yang L et al, Artif Cell Blood Sub(2004), 32: 519-528

Table 11. Grading of clinical manifestation pre and $5^{\text {th }}$ day after WBIA

The neuromuscular transmission function was evaluated by the stimulation of the deep peroneal nerve. The mean decrement of potentials evoked from the anterior tibial muscle, at three stimulation frequencies in the therapeutic rabbit group were determined. At $3 \mathrm{~Hz}$, the potential decreased from $21.87 \%$ to $17.87 \%$, at $5 \mathrm{~Hz}$, decreased from $22.25 \%$ to $18.75 \%$ and at $10 \mathrm{~Hz}$, decreased from $24.37 \%$ to $23.25 \%$. Table 12 shows the changes of the electrophysiological features of EAMG rabbits after WBIA which was on the 5th (D5) and the 8th (D8) day after passive transfer. The same RNS was performed in the control rabbit group, but no decrement was found, see Table 12

\begin{tabular}{lcccc}
\hline Frequency & \multicolumn{2}{c}{ Therapeutic group (\%) } & \multicolumn{2}{c}{ Control group (\%) } \\
\hline & D5 & D8 & D5 & D8 \\
\hline $3 \mathrm{~Hz}$ & $21.875 \pm 3.226$ & $17.875 \pm 1.642$ & $21.375 \pm 2.615$ & $21.125 \pm 2.416$ \\
\hline $5 \mathrm{~Hz}$ & $22.250 \pm 2.815$ & $18.750 \pm 1.388$ & $21.875 \pm 2.232$ & $22.000 \pm 1.772$ \\
\hline $10 \mathrm{~Hz}$ & $24.375 \pm 1.685$ & $23.250 \pm 1.388$ & $23.875 \pm 1.126$ & $24.125 \pm 2.696$ \\
\hline
\end{tabular}

Source: Yang L et al, Artif Cell Blood Sub(2004), 32: 519-528

Table 12. Comparison of the decrement of RNS between the therapeutic and the control group

The quantity of neuromuscular junction can reflect the neurotransmission function. On the 3rd day after WBIA (D8), the quantity of neuromuscular junction per unit area $\left(25 \mathrm{~mm}^{2}\right)$ of the therapeutic rabbit group was determined. Figure $\mathbf{1 1}$ shows the quantity of neuromuscular junction per unit area increased from $9.825 \pm 3.401$ to $10.90 \pm 2.879(\mathrm{P}<0.05)$ after WBIA, which was higher than that of the control group $(\mathrm{P}<0.01)$ 


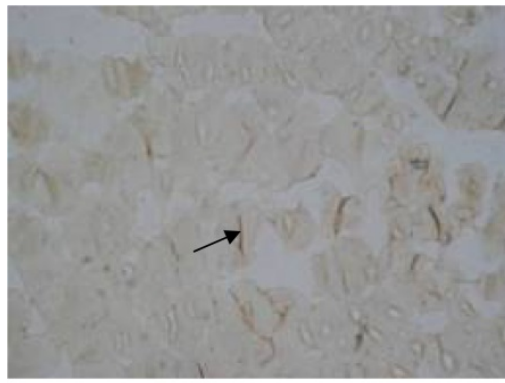

a

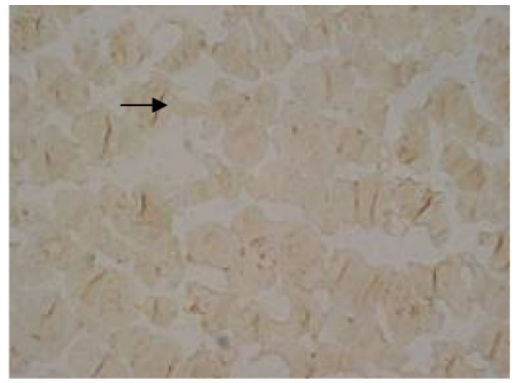

b

NOTE: $a$ and $b$ stand for the results before and after WBIA (From Li X H et al, Artif. Cell Blood Sub (2010), 38:186-191)

Figure 11. Neuromuscular junctions of the therapeutic rabbit group before and after WBIA on the 3rd day $(\times 200)$

In conclusion, extracorporeal whole blood sorbent-adsorption is an effective and safe approach in treating the passive experimental autoimmune myasthenia gravis by improving clinical manifestation, neuromuscular transmission function, enhancing the quantity of neuromuscular junction and antibody titer.

\section{Conclusion and future perspectives}

Intensive research and development of cellulosic bead type adsorbents by sorbent-perfusion in blood purification have paved a path for the treatment of patients with autoimmune diseases, hyperlipidemia and inflammatory disorders. Animal experiments and clinical trials have proved that it is safe, efficient and cost effective. Therefore, it is highly potential to be used clinically on patients for upgrading the quality of their living standard and prolonging their survival rates.

\section{Author details}

Shenqi Wang

College of Life Science and Technology \& Advanced Biomaterials and Tissue Engineering Center, Huazhong University of Science and Technology, 1037 Luoyu Road, Wuhan, P.R. China

Yaoting $\mathrm{Yu}$

The Key Laboratory of Bioactive Materials, Ministry of Education, Nankai University, Tianjin, P.R. China

\section{Acknowledgement}

The authors highly appreciate the financial support of Key project of National Basic Science and Development (G1999064707), the Project of 863 (N0.2002AA326060) and TianjinNankai University Co-Construction Foundation. 


\section{References}

[1] Behim E, Klinkmann H (1989) Selective and specific adsorbents for medical therapy. Int J Artif Organs. 12: 1-10.

[2] Lupien P J, Moorjani S, Awad J (1976) A new approach to the management of familial hypercholesterolaemia: removal of plasma cholesterol based on the principle of affinity chromatography, Lancet.1:1261-1265.

[3] Sinitsyn V V, Mamontova A G, Konovalov G A, Kukharchuk V V (1990) Apheresis of low density lipoproteins using a heparin-based sorbent with low antithrombin III binding capacity. Atherosclerosis. 84:55-59.

[4] Maaskant N, Bantjes A, Kempen H J M (1986) Removal of low density lipoprotein from blood plasma using cross-linked, sulfated polyvinylalcohol. Atherosclerosis. 62:159-166.

[5] Kojima S, Harada-Shiba M, Toyota Y, Kimura G, Tsushima M, Kuramochi M, Sakata T, Uchida K, Yamamoto A, Omae T (1992) Changes in coagulation factors by passage through a dextran sulfate cellulose column during low-density lipoprotein apheresis. Int J Artif Organs. 15:185-190.

[6] Yatzidis H (1964) Research on extrarenal purification with the aid of activated charcoal. Nephron. 72: 310-312.

[7] Terman D S, Petty D, Harbeck, Carr R I, Buffaloe G (1977) Specific removal of DNA antibodies in vivo by extracorporeal circulation over DNA immobilized in collodion charcoal. Clin. Immunol. Immunopathol. 8: 90-96.

[8] Falkenhagen D; Schima H; Loth F (1999) Arrangement for removing substances from liquids, in particular blood. United States Patent, \#5,855,782.

[9] Von Appen K, Weber C, Losert U, Schima H, Gurland H J, Falkenhagen D (1996) Microspheres based detoxification system: a new method in convective blood purification. Artif Organs 20: 420-425.

[10] Fang H, Wei J, Yu Y T (2004) In vivo studies of endotoxin removal by lysine-cellulose adsorbents. Biomaterilas. 25: 5433-5440.

[11] Zhao Y P, Huang M S, Wu W, Jin W (2009) Synthesis of the cotton cellulose based $\mathrm{Fe}(\mathrm{III})$-loaded adsorbent for $\operatorname{arsenic}(\mathrm{V})$ removal from drinking water. Desalination. 249:1006-1011.

[12] Kai Y, Hamada J-I, Morioka M, Yano S, Nakamura H, Makino K, Mizuno T, Takeshima $\mathrm{H}$, Kuratsu J-I (2006) Clinical evaluation of cellulose porous beads for the therapeutic embolization of meningiomas. AJNR Am J Neuroadiol.27: 1146-1150.

[13] Hamada J, Ushio Y, Kazekawa K, Tsukahara T, Hashimoto N, Iwata H (1996) Embolization with cellulose porous beads I An experimental study. AJNR Am J Neuroradiol .17:1895-1899.

[14] Hamada J, Kai Y, Nagahiro S, Hashimoto N, Iwata H, Ushio Y (1996) Embolization with cellulose porous beads II Clinical trial. AJNR Am J Neuroradiol .17: 1901-1906.

[15] Kai Y, Hamada J-I, Morioka M, Yano S, Nakamura H, Makino K, Mizuno T, Takeshima H, Kuratsu J-I (2007) Preoperative cellulose porous beads for therapeutic embolization of meninggioma:provocation test and technical considerations. Neuroradiology. 49:437443. 
[16] Wang D M, Hao G, Shi Q H, Sun Y (2007) Fabrication and characterization of superporous cellulose bead for high-speed protein chromatography. J Chromatogr A. 1146:32-40.

[17] Bai Y X, Li Y F (2006) Preparation and characterization of crosslinked porous cellulose beads. Carbohyd Polym. 64:402-407.

[18] Du K F, Yan M, Wang Q Y, Song H (2010) Preparation and characterization of novel macroporous cellulose beads regenerated from ionic liquid for fast chromatography. J Chromatogr A. 1217:1298-1304.

[19] Wang H F, Li B, Shi B L (2008) Preparation and surface acid-base properties of porous cellulose. BioResources. 3: 3-12.

[20] Thummler K, Fischer S, Feldner A, Weber V, Ettenauer M, Locth F, Faulkenhagen D (2011) Preparation and characterization of cellulose microspheres. Cellulose.18:135-142.

[21] Weber V, Ettenauer M, Linsberger I, Loth F, Thummler K, Feldner A, Fisher S, Faukenhagen D (2010) Functionalization and application of cellulose microparticles as adsorbents inextracorporeal blood purification. Macomol.Symp. 294- II :90-95.

[22] Weber V, Linsberger I, Ettenauer M, Loth F, Hoyhtya M, Faulkenhagen D (2005) Development of specific adsorbents for human tumor necrosis factor- $\alpha$ : Influence of antibody immobilization on performance and biocompatibility. Biomacromolecules. 6:1864-1870.

[23] Zhou H M, Wang H R (1998) Chemical Modification of Proteins. Beijing: Tsinghua University Press.19 p.

[24] Wang S Q, Li C M, Guo X J, Yu Y T, Wang W C (2008) Interaction Study of LDL with Charged Ligands for Effective LDL-C Removing Adsorbents. React Funct Polym. 68: 261-267.

[25] Wang L Y, Lu J, Yu Y T (2004) Interaction of Rheumatoid Factor with Immobilized ssDNA. Chem Res Chinese U. 20: 795-800.

[26] Yang Y (2002). Agarose resin for removal of rheumatoid arthritis factors. Master thesis.

[27] Hou K C, Zaniewski R (1991) Protein A immobilized cartridge for immunoglobulin purification. Biotechnol. Appl. Bioc. 13: 257-268.

[28] Adrian M, Roberto F-L, Jose' M G (2000) Essential role of the concentration of immobilized ligands in affinity chromatography: Purification guanidinobenzoatase on an ionized ligand. J Chromatogr B. 740: 211-218.

[29] Chu J Q, Zhang W H, Yu Y T, Zhu B R, Chen C Z (2004) In vitro studies of the immunoadsorbent for removal of IgA-nephropathy(III). Chem J Chinese U. 25: 14541457.

[30] Leckband D E, Kuhl T, Wang H K, Herron J, Muller W, Ringsdorf H (1995) 4-4-20 antifliorescyl IgG Fab' recognition of membrane bpund hapten: direct evidence for the role of protein and interfacial structure. Biochemistry-US. 34: 11467-11478.

[31] Zalipsky S (1995) Chemistry of polyethylene glycol conjugates with biological active molecules. Adv Drug Deliver Rev.16: 157-182.

[32] Harris M J, Struck C E, Case G M, Paley S M, Yalpanic M, Van Alstine M J, Brooks E D (1984) Synthesis and characterization of poly(ethylene glycol)derivatives. J Polym Sci. 22: 341-352. 
[33] Soltys J P, Etzel R M (2000) Equilibrium adsorption of LDL and gold immunoconjugates to affinity membranes containing PEG Spacers. Biomaterials. 21: 37-48.

[34] Wang S Q, Guo X J, Wang L Y, Wang W C, Yu Y T (2006) Effect of PEG Spacer on Cellulose Adsorbent for the Removal of Low Density Lipoprotein Cholesterol. Artif Cell Blood Subs. 34: 101-112.

[35] Armstrong V W, Windisch M, Wieland H, Fuchs C, Rieger J, Kostering H, Nebendahl K, Scheler F, Seidel D (1983) Selective continuous extractacorporeal ekimination of lowdensity lipoprotein with heparin at acidic $\mathrm{pH}$. Trans. Am Soc. Artif. Intern Organs. 29: 323-327.

[36] Cao N N, Yu Y Y, Wang M Y, Chen C Z. In vitro study of a novel low density lipoprotein adsorbent (2002), Artif Cell Blood Sub. 30:53-61.

[37] Sato Y, Agishi T (1996) Low -density lipoprotein adsorption for arteriosclerotic patients. Artif. Organs. 20: 324-327.

[38] Chen B, Pan J L, Tong M R, Yu Y T (1993) A study of adsorbents for the adsorption of low density lipoprotein (LDL). Ion Exch Adsorption. 9: 330-334.

[39] Sreenivasan K (1997) Synthesis and evaluation of cyclodextrin 2 hydroxyethy methacrylate copolymer as anovel adsorbent. Polym Int. 42:22-24.

[40] Bosch T (1996) Low density lipoprotein hemoperfusion using a modified polyacrylate adsorber:in vitro, exvitro and first clinical results. Artif Organs. 204: 344-345.

[41] Bosch T, Schmidt B, Kleophas W, Gillen C, Otto V, Passlick-Deetjen J, Gurland H J (1997) LDL hemoperfusion-a new procedure for LDL apheresis: first clinical application of an LDL adsorber compatible with human whole blood. Artif Organs. 209: 977-982.

[42] Wang S Q, Yu Y T, Cui T, Cheng Y (2002) Cellulose amphiphilic adsorbent for the removal of low density lipoprotein. Artif Cell Blood Subs. 30: 285-292.

[43] Cheng Y, Wang S Q, Yu Y T, Yuan Y (2003) In vitro, in vivo studies of a new amphiphilic adsorbent for the removal of low-density lipoprotein. Biomaterials. 24: 2189-2194.

[44] Chapman M J (1980) Animal lipoproteins: chemistry, structure and comparative aspects. J Lipid Res. 21: 789-853.

[45] Wang T, Wang W C, Wang L Y, Wei D, Wang S Q, Yu Y T, Kong D L (2008) Phosphatebased affinity adsorbents for the removal of low density lipoprotein: Preparation and In vitro Adsorption capability test. Chinese J Biomed Eng. 27:132-136.

[46] Yu H F, Fu G Q, He B L (2007) Preparation and adsorption properties of PAA-grafted cellulose adsorbent for low density lipoprotein from human plasma. Cellulose. 14: 99107.

[47] Arnett F C, Edworthy S M, Bloch D A, Mcshane D J, Fries J M, Cooper N S, Healey L A, Kaplan L A, Liang M H, Luthra H S, Medsger T A, Mitchell D A, Neustadt D H, Pinals R S, Schaller J G, Sharp J T, Wilder R, Hunder G G (1988) The 1987 revised ARA criteria for rheumatoid arthritis Rheum. Arthritis and Rheumatism. 31: 315-324.

[48] Raetz C R H. Biochemistry of endotoxins (1990) Annu Rev Biochem. 59:129-170.

[49] Callery M P ,Kamei T, Mangino M J, Flye M W (1991) Organ interactions in sepsis. Host defense and the hepatic-pulmonary macrophage axis. Arch Surg-Chicago. 126: 28-32. 
[50] Kong D L, Chen C Z, Lin E F, Yu Y T (1998) Clinical trials of type I and invitro studies of type II immunoadsorbents for systemic lupus erythematosus therapy. Artif Organs. 22: 644-650.

[51] Yang L, Cheng Y, Yan W R, Yu Y T (2004) Extracorporeal whole blood immunoadsorption of autoimmune myasthenia gravis by cellulose tryptophan adsorbent. Artif Cell Blood Sub. 32: 519-528.

[52] Li X H, Cheng Y, Yang L, Wang S Q, Yu Y T (2010) Extracorporeal whole blood immune-adsorption of passively transferred myasthenia gravis rabbits by cellulosetryptophan column. Artif Cell Blood Sub. 38:186-191. 